\title{
Obituary
}

\section{Dr. Terence Isaac Perera}

\section{FRCP, FAAP, FIAP, FCCP (1923-2012)}

Sri Lanka Journal of Child Health, 2012: 41(4): 213-214

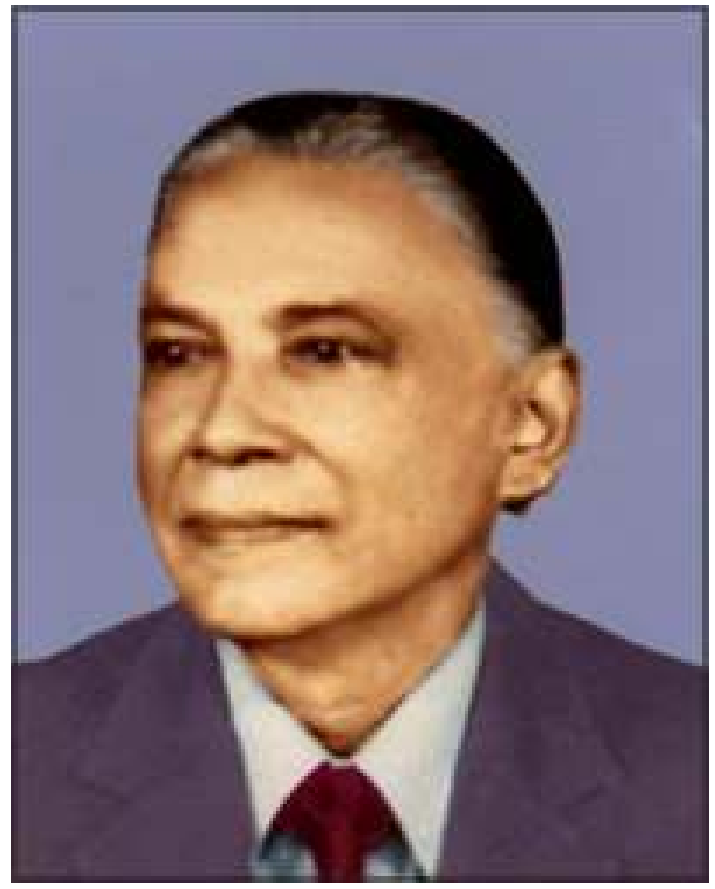

Dr Terence Perera, pioneering paediatrician, public health expert, prolific writer and philanthropist passed away on $2^{\text {nd }}$ July 2012, at the age of 89 years. His career was marked by many professional achievements but this unassuming, soft-spoken and gentle man shied the limelight.

The middle child of a family of three children, he travelled daily to St Joseph's College Colombo, in an ox drawn buggy-cart and excelled in studies. He was also a sprinter and a swimmer of repute. Education continued at the Colombo Medical College. He graduated with MBBS (Second Class Honours) in 1948, obtained DCH (University of London) in 1956, MRCP (Royal College of Physicians Glasgow) in 1961 and Diploma in MCH (University of Uppsala Sweden) in 1965.

In 1963, Dr. Terence Perera became the first-ever Consultant Paediatrician to serve in North Central Province of Sri Lanka, when he was appointed to the Government Hospital in the ancient capital of Anuradhapura. He diligently served in this area where a large and poorly resourced peasantry lived.
At the end of his first day of work, as darkness gathered, he rang our door bell. This was when I first met him. Although strangers would not normally be entertained, this distinguished looking caller was not turned away. I well remember, as a young child, curiously, periodically peeping at this lone stranger as he sat patiently, several long hours until my parents returned home. It then transpired that the newly appointed paediatrician had come to the fellow obstetrician (my father), to seek help. Those were days when provision of accommodation was not the concern of hospital authorities, whose stance was "service should be provided, even by living on a tree". Hotels were nonexistent, tourism yet to become an industry. Thus began a long and lasting friendship between our two families!

Dr. Perera served the Ministry of Health from 1962-68 and was Consultant Paediatrician in Anuradhapura and Kalutara. He then took the unusual and bold step of shifting gears from individual patient care to population paediatrics. Thereafter Maternal and Child Health (MCH) became his life's work. He was placed at the helm of the newly created Maternal and Child Health Bureau and when this organisation was re-designated Family Health Bureau (FHB), Dr. Terence Perera became its first Director (1968-1970).

Greater things followed when responsibilities expanded from national to international level. World Health Organisation (WHO) recruited him to its South East Asia Regional Office in New Delhi. From 1971 to 1983 he did his motherland proud by being Senior Adviser on Family Health to South East Asia region. Based on his in-depth knowledge and personal experience of local needs, acquired as a Provincial Paediatrician and Director FHB, he ensured that Sri Lankan health systems and professionals received maximum assistance in all areas of MCH. From 1984 to 1986 he was WHO Consultant in Indonesia.

Many honours and awards testify to the high quality of Dr. Terence Perera's work. He received the Fellowship of the Royal College of Physicians Glasgow in 1971, Honorary Fellowship of American Academy of Paediatrics in 1981, Plaque of Honour, 
Paediatric Academy of Thailand in 1983, Fellowship of Indonesian Academy of Paediatrics in 1984, Fellowship of Ceylon College of Physicians in 1989, Fellowship of Sri Lanka College of Paediatricians in 1997 and Plaque of Honour from the Family Health Bureau, Sri Lanka in 2000.

Dr. Terence Perera published widely in international scientific journals and print media. In retirement he authored a book titled "Peep into the Past, and a Look into the Future", a compilation of his writings. It testifies to far thinking and varied advocacies of this stalwart - on breast feeding, keeping multi-national milk food companies at bay, and child health services in resource-poor settings.

In his private life too, he was blessed. Marriage to beautiful Lakshmi Wickremesinghe lasted 58 happy years, until she predeceased him. Their three children continue to excel in fields close to their father's heart. Malati is a nutritionist, Neloufa and husband Alex Merill are both paediatricians in Bakersfield California, and son Rohanta is a general practitioner in West Midlands, UK.

Dr. Perera enjoyed travelling extensively. He kept detailed diaries, meticulously noting "good food", "ocean view rooms" etc. which at a later date came handy to other travellers! It is no surprise that his numerous articles to Sri Lankan newspapers ranged from health dilemmas to travel insights.
It was in such an article in 2009 that he mentioned the athletic successes of granddaughter Christine Sonali Merrill, prompting the Sri Lankan Athletic Association to contact her via the Sri Lankan embassy in US and her representing Sri Lanka as an Olympian.

Dr. Terence Perera was a humanitarian and a philanthropist. He volunteered his services weekly to treat displaced refugees from Jaffna, founded a Trust fund for secondary education of gifted, needy children and supported many other charities in Sri Lanka.

I thank the Sri Lanka Journal of Child Health for granting my request to pen an appreciation on "Uncle Terry", the paediatrician who silently but surely worked behind the scenes to help Sri Lanka achieve exemplary health statistics - a Sri Lankan who has most definitely "left his foot prints in the sands of time".

Professor Manouri P. Senanayake Head, Department of Paediatrics, University of Colombo 